\title{
Comparison between the spastic paraplegia rating scale, Kurtzke scale, and Osame scale in the tropical spastic paraparesis/myelopathy associated with HTLV
}

\author{
Comparação entre a escala para paraplegia espástica, escala de Kurtzke e escala de Osame, na \\ paraparesia epástica tropical/mielopatia associada ao HTLV
}

\author{
Rodrigo Antonio Rocha da Cruz Adry ${ }^{1,2,3}$, Catarina Cöuras Lins ${ }^{4}$, Ramon de Almeida Kruschewsky \\ and Bernardo Galvão Castro Filho ${ }^{6}$
}

\begin{abstract}
Introduction: The objective of this study was to compare Osame's scale of motor incapacity and the expanded scale of the state of incapacity of Kurtzke with the spastic paraplegia rating scale for the clinical evaluation of patients with HTLV-I-associated myelopathy/tropical spastic paraparesis (HAM/TSP). Methods: Patients with the diagnosis of infection by HTLV-I/HTLV-II and with the clinical suspicion of HAM/TSP were included in the study. Results: There were 45 patients who were evaluated. When analyzing the results of the scales, the researchers found the following averages of 21.08 points for the spastic paraplegia rating scale, 4.35 points for Osame's scale, and 4.77 points for Kurtzke's scale. The relation between the scale of paraplegia with Osame's was very significant with $\mathrm{p}<0.0001$, and regarding Kurtzke's scale, there was a similar result of $\mathrm{p}<0.0001$. When comparing Osame's, Kurtze's, and the spastic paraplegia rating scale with the time of disease, the researchers found a significant result of $p=0.0004$ for the scale of spastic paraplegia, $p=0.0018$ for Osame's scale, and $p<0.0001$ for Kurtzke's scale. Conclusion: The spastic paraplegia rating scale has a good relation with Osame's and Kurtzke's scales showing a p index that is very significant that indicates that, although the scale was not initially made to be applied to patients with HAM/TSP because of the infection by HLTV, it showed to be as efficient as Osame's and Kurtzke's scales in evaluating the patients' neurological conditions.
\end{abstract}

Keywords: HTLV. HAM/TSP. Osame. Kurtzke. Spasticity. Scale.

\section{RESUMO}

Introdução: $\mathrm{O}$ objetivo deste estudo foi comparar a escala de incapacidade motora de Osame e a escala expandida do estado de incapacidade de Kurtzke com a escala para avaliação da paraplegia espástica com o objetivo de avaliar a clinica dos pacientes com mielopatia associada a HTLV-I/paraparesia espastica tropical (PET/MAH). Métodos: Foram incluídos pacientes com diagnóstico de infecção pelo HTLV-I/HTLV-II e a suspeita clinica de PET/MAH. Resultados: Foram avaliados 45 pacientes. Ao analisar os resultados das escalas encontramos as seguintes médias de 21,08 pontos para a escala para paraplegia espástica, 4,35 pontos para a escala de Osame e 4,77 pontos para a de Kurtze. A relação entre a escala de paraplegia com a de Osame foi muito significativa com $\mathrm{p}<0.0001$, e com relação a escala de Kurtze obteve resultado semelhante com $\mathrm{p}<0.0001$, também significante. Comparando-se as escalas de Osame, Kurztze e escala para avaliação da paraplegia espástica com o tempo de doença obtivemos um resultado significante com $\mathrm{p}=0,0004$, para a escala de paraplegia espastica, $\mathrm{p}=0,0018$ para a escala de Osame e p $<0,0001$ para a escala de Kurtzke. Conclusões: A escala da paraplegia espástica possui boa relação com as escalas de Osame e Kurzte, mostrando um p muito significativo, indicando que apesar da escala não ter sido feita inicialmente para ser aplicada aos pacientes com PET/MAH devido à infecção pelo HLTV, ela se mostrou capaz de ser tão eficiente quanto às escalas de Osame e Kurtzke para avaliar o quadro neurológico dos pacientes.

Palavras-chaves: HTLV. HAM/TSP. Osame. Kurzte. Espasticidade. Escala.

1. Departamento de Neurocirurgia, Hospital de Base de São José do Rio Preto, Faculdade de Medicina de São José do Rio Preto, São José do Rio Preto, SP. 2. Serviço de Neurologia e Neurocirurgia, Hospital Geral Roberto Santos, Salvador, BA. 3. Serviço de Neurologia e Neurocirurgia, Hospital Geral do Estado, Salvador, BA. 4. Faculdade de Medicina, Escola Bahiana de Medicina e Sáude Pública, Salvador, BA. 5. Disciplina de Neurologia, Faculdade de Tecnologia e Ciências, Salvador, BA. 6. Laboratório Avançado de Saúde Pública, Centro de Pesquisas Gonçalo Moniz, Fundação Oswaldo Cruz, Salvador, BA

Address to: Dr. Rodrigo Antonio Rocha da Cruz Adry. Polissonografia/Hospital de Base de São José do Rio Preto/FAMERP. Av. Brigadeiro Faria Lima 5544/6º andar, Vila São Pedro, 15090-000 São José do Rio Preto, SP, Brasil.

Phone/Fax: 5517 3201-5000

e-mail: rodrigoadry@yahoo.fr

Received in 18/06/2011

Accepted in 10/01/2012

\section{INTRODUCTION}

Human T lymphotropic virus type 1 (HTLV-I) was first identified in Brazil in 1986, among Japanese immigrants from Okinawa, residing in the City of Campo Grande, State of Mato Grosso do Sul. Prevalence rates of $13 \%$ in the immigrants and $8 \%$ in their descendents were observed. However, it was only in 1988 that MacHann et al. were able to isolate the virus ${ }^{1}$. A few years after the identification of HTLV-I, a second type of lymphotropic virus T, was isolated from the lymphocytes of a patient with leukemia of hairy cells ${ }^{2,3}$.

The virus HTLV I and II are from the Retroviridae family, and their distribution is variable according to the studied population ${ }^{4,5}$. The virus has preferential tropism for lymphocytes CD4+, and it is transmitted in three ways: sexual, blood, and vertical ${ }^{2,5-9}$.

The virus HTLV-I is associated with many human pathologies, such as leukemia/lymphoma of T cells of adults and HTLV-I-associated myelopathy/ tropical spastic paraparesis (HAM/TSP) $)^{4,10-13}$. Spastic paresis caused by HTLV-I is a chronic demyelinizing disease with the presence of a myelopathy that is slowly progressive ${ }^{14}$.

A diagnostic criterion has not been well established yet; parameters have been described by the World Health Organization as weakness in the legs, diffused hyperreflexia, clonus, loss of vibratory sensitiveness, and urinary disturbances ${ }^{15}$. Diagnosis usually requires the presence of virus or antibodies of the virus in the blood or liqueur ${ }^{15}$.

Osame's scale of motor incapacity and Kurtzke's expanded scale of the state of incapacity are used to evaluate the patients who suffer from HAM/TSP by HTLV-I; however, these scales do not demonstrate subtle improvement or worsening in the patient's clinical condition. Schüle et al. ${ }^{16}$ developed a scale for the evaluation of spastic paraplegia for other types of spasticity but of easy application for patients with HTLV. 
Therefore, the objective of this work was to compare Osame's scale of motor incapacity and Kurtzke's expanded scale of the state of incapacity with the scale for spastic paraplegia rating scale (SPRS) with the aim of evaluating the clinical situation of patients with HAM/TSP, through an instrument functionally developed for spasticity.

\section{METHODS}

It was a transversal study, and it was conducted through reviewing the medical promptbook that consists of a specific protocol for HAM/TSP of the patients who had consultations in the clinic of HTLV.

The patients' promptbooks were from the clinic of the Center of HTLV from the Bahian School/Bahian Foundation for the Development of Sciences/Oswaldo Cruz Foundation. The patients had consultations between the periods of June 2008 and April 2009.

Patients included were the ones diagnosed with the infection of HTLV-I/HTLV-II through the exams ELISA and Western blot with the localization of the antibodies, anti-HTLV-I/ HTLV-II, or the localization of the virus in the blood or liqueur. They must be eighteen years old or older and have the clinical suspicion of HAM/ TSP after neurological evaluation.

Patients excluded from the study were those with cognitive deficit and/or psychiatric disturbance, impossibility of answering the questionnaire, other neurological diseases or any disease that can influence in answering the questionnaires, or when there is doubt about the patient's diagnosis.

The used promptbook has a specific protocol for HTLV that contains the patient's personal data, time of disease, medical and familiar antecedents, progression of disease, neurological exam, and laboratorial exams (viral load for HTLV, HTLV's serotype). The specific scales that were used for the patients' clinical evaluation were Osame's scale of motor incapacity, Kurtzke's expanded scale of the state of incapacity, and the SPRS.

In these cases, the analysis was evaluated through measures of frequency, averages, medians, and pattern deviations. To analyze the concordance of scales, graphs of dispersion were used to visualize the concordance between the three scales that were studied, comparing the scale of spastic paraplegia with Osame's and Kurtzke's. To estimate the equations of straight line that better represented the relations between the scales and to compare them with the ideal one, the simple regression analysis method was used. The set level of significance for the analysis was 5\%. P values lower than 0.05 were considered statistically significant.

All participating individuals were briefed on the study and signed a free, informed consent form before the collection of samples.

\section{Ethical considerations}

The study was approved by the human ethics committee of the Bahia School of Medicine and Public Health.

\section{RESULTS}

During the period of collection, 45 patients were evaluated; among these, $30(66.7 \%)$ were female, 15 (33.3\%) were male, 43 (95.6\%) were infected by HTLV-I, and 2 (4.4\%) were infected by HTLV-I/II. Through the demographic characteristics, it was observed that the mean age was 52.3 years: 54.8 years for males and 50.8 years for females. Regarding the duration of the disease, the average was 8.9 years, with males having a duration of 10.5 years and females with a duration of 8.13 years.

Regarding the signs and symptoms, the researchers found the following: paraparesis in inferior members of $88.9 \%$ (40), paraparesis in superior members of $11.1 \%$ (5), hyperreflexia in superior members of $48.9 \%$ (22), hyperreflexia in inferior members of 93.3\% (42), Babinski's sign in 86.7\% (39), Hoffman's sign in $33.3 \%$ (15), Tromner's sign in $28.9 \%$ (13), spasticity in $82.2 \%$ (37), clonus in $73.3 \%$ (33), spastic march in $86.7 \%$ (39), altered sensitivity in $8.9 \%$ (4), paresthesia in $75.6 \%$ (34), urinary disturbance in $82.2 \%$ (37), intestinal constipation in $42.2 \%$ (19), lumbar pain in $57.8 \%$ (26), and erectile dysfunction in $17.8 \%$ (8) of the patients.

When analyzing the results of the scales, the researchers found the following averages: $21.08( \pm 10.9)$ points for the scale for spastic, $4.35( \pm 2.15)$ points for Osame's scale, and $4.77( \pm 1.7)$ points for Kurtzke's scale. Correlation of SPRS with Osame's and Kurtzke's scales was also evaluated. The relationship between the scale of paraplegia and Osame's was very significant, with $\mathrm{p}<0.0001$. For Kurtzke's scale, the result was similar with $\mathrm{p}<0.0001$, also a significant one (Figures 1 and $\mathbf{2}$ ).

Comparing Osame's and Kurtzke's scales and the SPRS on the duration of diseases, the researchers obtained significant results, with $p=0.0004$ for the scale of spastic paraplegia, $p=0.0018$ for Osame's scale, and $\mathrm{p}<0$ for Kurtzke's scale (Figures 3, 4, and 5).

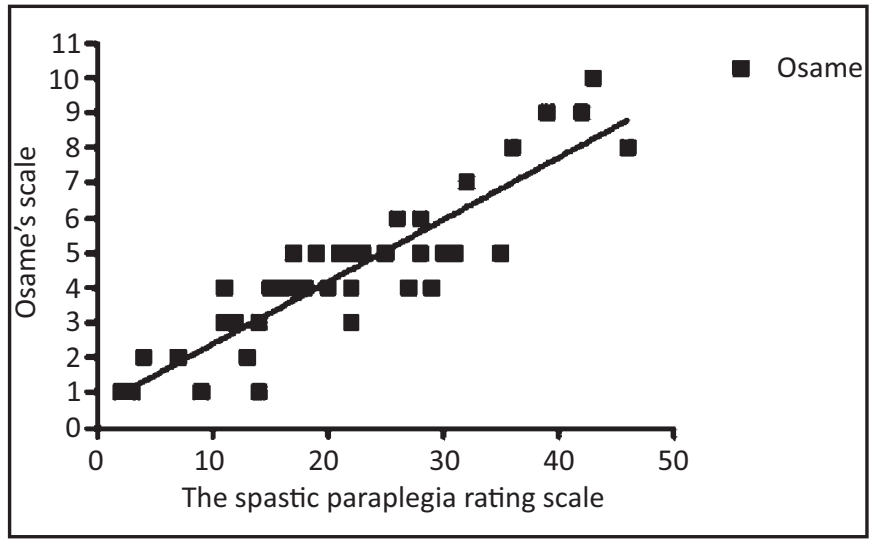

FIGURE 1 - Correlation between the scale for spastic paraplegia rating scale (SPRS) and Osame's scale.

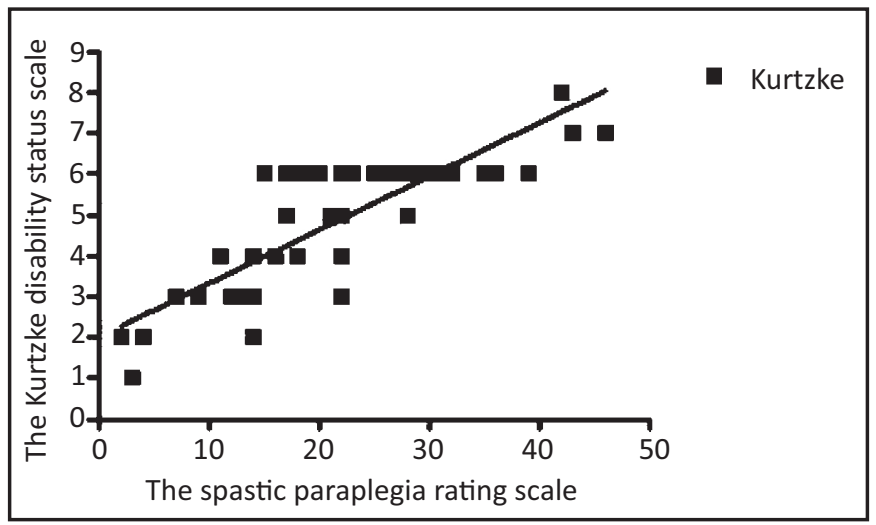

FIGURE 2 - Correlation between SPRS and Kurtzke's scale. 


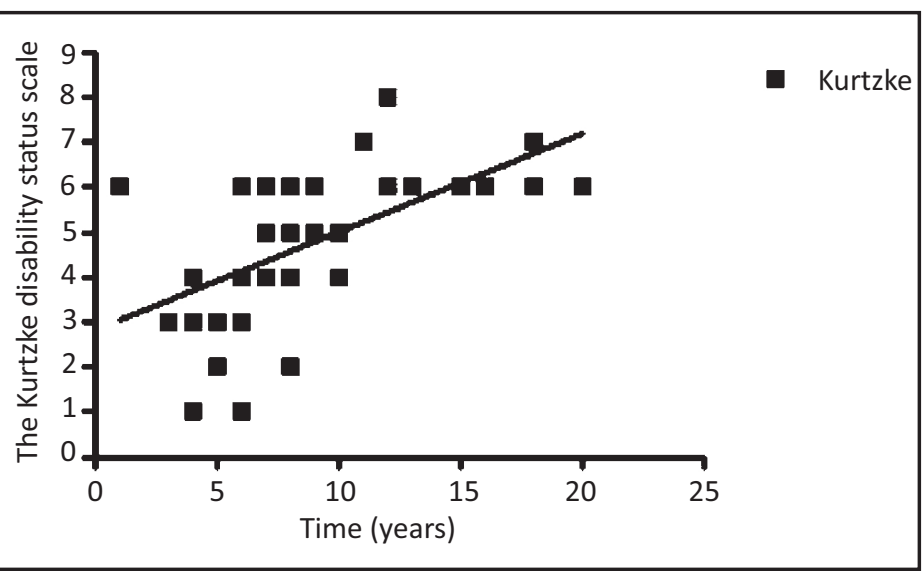

FIGURE 3 - Comparison between Kurtzke's scale and duration of disease.

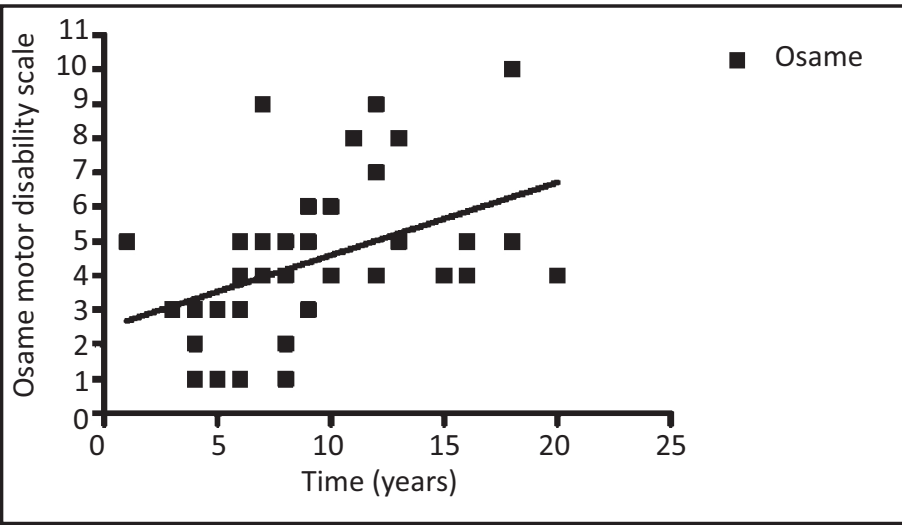

FIGURE 4 - Comparison between Osame's scale and duration of disease.

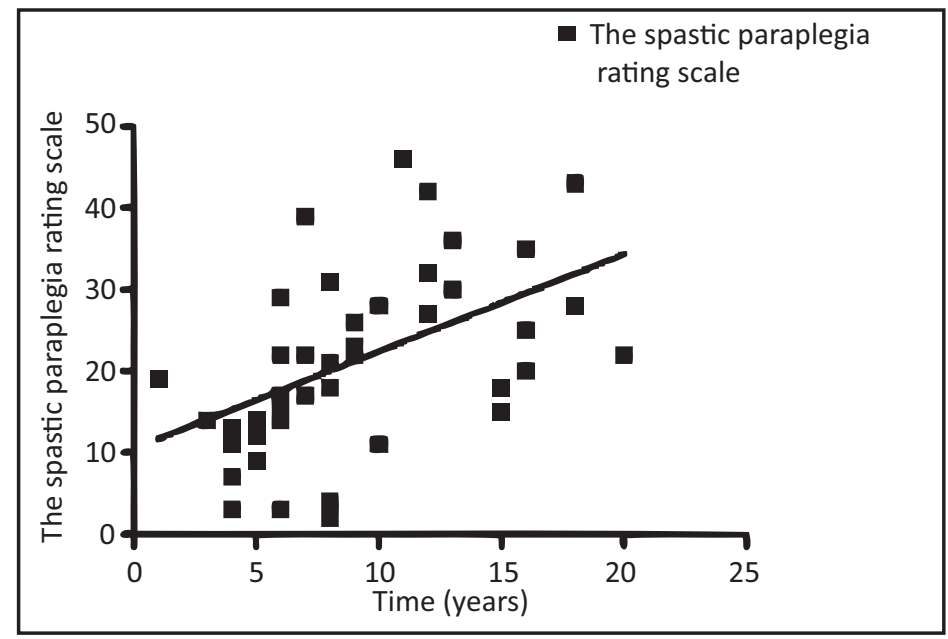

FIGURE 5 - Comparison between the spastic paraplegia rating scale (SPRS) and duration of disease.

\section{DISCUSSION}

The virus for HTLV has a worldwide distribution ${ }^{17}$. Statistics point out that there are 15 to 20 million people infected by HTLV-I worldwide $\mathrm{s}^{5,9,10,17,18}$. Brazil has been pointed out as the country with the highest absolute number of seropositive individuals for HTLV-I and HTLV-II in the world, and it has also demonstrated a heterogeneous distribution, depending on the ethnic group and geographic localization ${ }^{19}$. It is estimated that 2.5 million people are infected by HTLV-I in Brazil ${ }^{2,10}$. Epidemiological studies suggest that
Salvador, the capital of the State of Bahia, in the northeast of Brazil, has the highest prevalence of infection by HTLV-I, when compared with other big Brazilian cities ${ }^{9}$. Among blood donors in Brazil, the highest seroprevalence of bearers with anti-HTLV-I (1.5\%) was detected in Salvador, State of Bahia, comparing with other capitals such as Manaus (0\%), Recife $(0.3 \%)$, Rio de Janeiro $(0.3 \%)$, and Florianópolis $(0.08 \%)^{2,3,9}$. The infection by HTLV-I is endemic in Japan and in many tropical countries where seroprevalence varies between $6 \%$ and $30 \%$. Among these infected individuals, $5 \%$ to $10 \%$ usually develop not only HAM but PET as well ${ }^{9}$. Endemic cases of spastic paraparesis have been related worldwide, mainly in Japan, Malaysia, Equatorial Africa, and the Caribbean ${ }^{2,17,20}$. It is known that in endemic regions, the prevalence increases with age, and it is higher in females ${ }^{6}$. Dourado et al. ${ }^{21}$ related that seroprevalence in Salvador, because of the infection by HTLV-I, was $1.7 \%-1.2 \%$ for males and $2 \%$ for females, which corroborate with the highest prevalence in female subjects. It has been related that this disease affects between $0.2 \%$ and $5 \%$ of individuals after forty years old. From the studied population, we can notice that demographic aspects, such as more women acquiring the disease, were compatible with the ones that had been identified in the clinical study by Orland et al. ${ }^{15}$, about the prevalence and clinical characteristics of the neurological disease of HTLV. However, in that study, the dominant age was determined mainly between 40 and 49 years old, which is different from what was observed in the present study where the mean age was 52.3 years. It can be related to the late diagnosis of the disease because of the difficult access of the population to specialized services or the difficulty of medical teams in identifying the disease.

The reason why $95 \%$ of the people who are infected by HTLV-I are asymptomatic is not known; the physiopathology that activates the symptomatic state and the reason for the tropism of the virus are not fully understood ${ }^{8}$. Although the immune pathogenic mechanisms that are specific of PET/ $\mathrm{MAH}$ have not been totally clarified, diverse studies have demonstrated the participation of the immune system in the development or maintenance of this neurological disorder ${ }^{17,18}$. The spastic paraparesis caused by HTLV-I is a demyelinizing chronic disease, with the presence of a slowly progressive myelopathy ${ }^{14}$. The pathogenicity of the agent is not only restricted to the pyramidal motor system; Kuate et al. ${ }^{11}$ reported two cases of cerebellar syndrome associated with an infection by HTLV-I. The incidence of HAM/TSP is lower than $1 \%$, which suggests that for HAM/TSP to exist, there are necessary viral factors and conditions of the host $\mathrm{t}^{10,14}$. Other studies show that this incidence rate of HAM/TSP is in $4-5 \%$ of the people infected by HTLV-I ${ }^{12,15}$. The main neurological findings are spastic paraparesis, lumbar pain, sensorial disturbance on inferior members, and urinary disturbance ${ }^{11,14,22}$. Despite the typical presentation of HAM/TSP, there is an increase in the number of studies that indicate an extrapyramidal pathogenic model. Subcortical and periventricular lesions of the white mass have been described in magnetic resonances of the brain. That is why some authors propose the change of the term myelopathy associated with HTLV-I to myeloneuroencephalopathy related to HTLV-I ${ }^{11}$. Other neurological disorders are associated with HTLV-I, as isolated peripheral neuropathy, and a condition similar to amyotrophic lateral sclerosis ${ }^{23}$. Regarding the clinical 
findings in the work that characterize the tropical spastic paraparesis, a compatibility with a big study carried out by the Work Group of Infectious Disease from the Nervous System - Brazilian Academy of Neurology was observed.

The results also showed that the scale of spastic paraplegia has a good relation with Osame's and Kurtzke's scales, showing a very significant $\mathrm{p}$ value that indicates that despite not having initially applied to patients with HAM/TSP because of the infection by HTLV, it is shown to be as efficient as Osame's and Kurtzke's scales to evaluate the patients' neurological condition. As there are no studies yet on the use of the scale of paraplegia for the patients with HAM/TSP, the researchers could not correlate the results with those of the other authors. Nevertheless, the study showed that its use is promising. Once the scale presents a more detailed evaluation of a patient as a whole, in this way, there is a better classification of a patient's condition.

We can see in Figures 2 and $\mathbf{3}$ that many patients who had similar scores in Osame's and Kurtzke's scales had a different result in the scale for spastic paraplegia. Thus, it indicates that, probably, this last one identifies signs and symptoms that are more subtle and not observed by the first two. Regarding the duration of the diseases and the scales, the study showed that all of them have a significant relation, that is, the longer the duration of the disease, the bigger the tendency of a higher punctuation in the scales, mainly for the scale for the SPRS and Kurtzke scale. However, more studies are necessary to evaluate more details with which scale represents, with much fidelity, the duration of a disease. A scale can be more sensitive to the alterations of signs and symptoms than others. Thus, the results demonstrate that the scale of spastic paraplegia may be useful to help create a more detailed scale for another HAM/TSP occurrence. Perhaps, it can even be used in full, but further studies are needed to verify its application in patients infected by HTLV.

\section{CONFLICT OF INTEREST}

The authors declare that there is no conflict of interest.

\section{FINANCIAL SUPPORT}

This study was supported by the Fundação de Amparo à Pesquisa do Estado da Bahia (FAPESB).

\section{REFERENCES}

1. Roman GC, Roman LN. Tropical spastic paraparesis. A clinical study of 50 patients from Tumaco (Colombia) and review of the worldwide features of the syndrome. J Neurol Sci 1988; 87:121-138.

2. Carneiro-Proietti AB, Catalan-Soares BC, Castro-Costa CM, Murphy EL, Sabino EC, Hisada M, et al. HTLV in the Americas: challenges and perspectives. Rev Panam Salud Publica 2006; 19:44-53.

3. Gessain A, Barin F, Vernant JC, Gout O, Maurs L, Calender A, et al. Antibodies to human T-lymphotropic virus type-I in patients with tropical spastic paraparesis. Lancet $1985 ; 2: 407-410$.

4. Britto APCR, Galvão-Castro B, Straatmann A, Santos-Torres S, Tavares-Neto J. Infecção pelo HTLV-I/II no Estado da Bahia. Rev Soc Bras Med Trop 1998; 31:35-41.
5. Moxoto I, Boa-Sorte N, Nunes C, Mota A, Dumas A, Dourado I, et al.. Perfil sociodemográfico, epidemiológico e comportamental de mulheres infectadas pelo HTLV-1 em Salvador-Bahia, uma área endêmica para o HTLV. Rev Soc Bras Med Trop 2007; 40:37-34.

6. Calatan-Soares B, Proietti FA, Carneiro-Proietti ABF. Os virus linfotrópicos de células T humanos (HTLV) na última década (1990-200): aspectos epidemiológicos. Rev Bras Epidemiol 2001; 4:81-91.

7. Jacob F, Santos-Fortuna E, Azevedo RS, Caterino-de-Araujo A. Performances of HTLV Serological Tests in Diagnosing HTLV Infection in high-risk Population of São Paulo, Brazil. Rev Inst Med Trop Sao Paulo 2007; 49:361-364.

8. Khan RB, Bertorini TE, Levin MC. HTLV-1 and its neurological complications. Neurologist 2001; 7:271-278.

9. Mota A, Nunes C, Melo A, Romeo M, Boa-Sorte N, Dourado I, et al. A casecontrol study of HTLV-infection among blood donors in Salvador, Bahia, Brazil Associated risk factors and trend towards declining prevalence. Rev Bras Hematol Hemoter 2006; 28:120-126.

10. Best I, Adaui V, Verdonck K, Gonzalez E, Tipismana M, Clark D, et al. Proviral load and immune markers associated with human T-lymphotropic virus type 1 (HTLV-1)-associated myelopathy/tropical spastic paraparesis (HAM/TSP) in Peru. Clin Exp Immunol 2006; 146:226-233.

11. Kuate C, Yepnjio FN, Ngang P, Njamnshi AK. HTL-I infection presenting as a cerebellar syndrome in Yaounde Central Hospital (Cameroon). Afr J Neurol Sci 2006; 2:38-42.

12. Lopes IGL, Maia EL, Azevedo VN, Machado LFA, Ishak MOG, Ishak R, et al. Caracterização molecular do HTLV-1 em pacientes com parapares espástica tropical/mielopatia associada ao HTLV-1 em Belém, Pará. Rev Soc Bras Med Trop 2006; 39:504-506.

13. Takayanagui OM, Odashima NS, Milagres ACP. Estudo multicêntrico de HAM/ TSP no Brasil. Arq Neuropsiquiatr 1998; 56(supl I):31.

14. Machigashira N, Yoshida Y, Wang S, Osame M. HTLV-1-associated myelopathy/ tropical spastic paraparesis with pseudohypoparathyroidism. Neurology 2001; 56:104-106.

15. Orland JR, Engstrom J, Fridey J, Sacher RA, Smith JW, Nass C, et al. Prevalence and clinical features of HTLV neurologic disease in the HTLV Outcomes Study. Neurology 2003; 61:1588-1594.

16. Schule R, Holland-Letz T, Klimpe S, Kassubek J, Klopstock T, Mall V, et al. The Spastic Paraplegia Rating Scale (SPRS): A reliable and valid measure of disease severity. Neurology 2006; 67:430-434.

17. Proietti FA, Carneiro-Proietti AB, Catalan-Soares BC, Murphy EL. Global epidemiology of HTLV-I infection and associated diseases. Oncogene 2005; 6058-6068.

18. Coelho-dos-Reis JGA, Rocha RDR, Brito-Melo GEA, Ribas JG, CarneiroProietti ABF, Catalan-soares $\mathrm{B}$ et al. Avaliação do desempenho de parâmetros imunológicos como indicadores de progressão clínica da infecção crônica pelo HTLV-1. Rev Soc Bras Med Trop 2007; 40:29-36.

19. Jacob F, Santos-Fortuna E, Azevedo RS, Caterino-de-Araujo A. Performancesof HTLV Serological Tests in Diagnosing HTLV Infection in high-risk Population of São Paulo, Brazil. Rev Inst Med Trop Sao Paulo 2007; 49:361-364.

20. Galvão-Castro B, Lourdes L, Rodrigues LGM, Sereno A, Ferreira Junior OC, Franco LGP, et al. Distribution of human T-lymphotropic virus type I among blood donors: a nationwide Brazilian study. Transfusion 1997; 37:242.

21. Alcantara LCJ, Barreto ML, Teixeira MG, Galvão-Castro B. HTLV-I in the general population of Salvador, Brazil: a city with African ethnic andsociodemographic characteristics. J Acquir Immune Defic Syndr 2003; 34:527-531.

22. Jernigan M, Morcos Y, Lee SM, Dohan FC, Raine C, Levin MC. IgG in brain correlates with clinicopathological damage in HTLV-1 associated neurologic disease. Neurology 2003; 60:1320-1327.

23. Mühlau M, Bülow S, Stimmer H, Schätzl H, Berthele A. Seronegative EpsteinBarr virus myeloradiculitis in an immunocompetent 72 -year-old woman. Neurol 2005; 65:1329. 